\title{
Methods to Develop a Sustainable Free Eye Clinic at a Homeless Shelter
}

\author{
Lauren Hennein, MD ${ }^{1}$ Alejandra G. de Alba Campomanes, MD, MPH² Saras Ramanathan, MD ${ }^{3}$
}

1 Department of Ophthalmology, University of California San Francisco, San Francisco, California

2 Department of Ophthalmology, University of California San Francisco, San Francisco, California

3 Department of Ophthalmology, University of California San Francisco, San Francisco, California

J Acad Ophthalmol 2020;12:e22-e26.
Address for correspondence Saras Ramanathan, MD, Department of Ophthalmology, University of California San Francisco, 400 Parnassus Avenue, San Francisco, CA 94143 (e-mail: saras.ramanathan@ucsf.edu).
Homelessness is a major public health problem in the United States. ${ }^{1,2}$ According to the 2018 Annual Homeless Assessment Report to Congress, on a single night in 2018, more than 550,000 people were experiencing homelessness in the United States. ${ }^{3}$ A recent study showed that $4.2 \%$ of individuals in the United States experienced homelessness for at least 1 month at some point in their lives and $1.5 \%$ experienced homelessness in the past year. ${ }^{2}$ Eye health among the homeless community is of paramount importance, as poor vision makes this population particularly vulnerable and adds, significantly, to the social and health burdens.

The homeless population has been found to have high rates of uncorrected refractive error, ${ }^{4-7}$ cataract, $^{6-8}$ retinal disease, ${ }^{6}$ and glaucoma. ${ }^{7,8}$ Visual impairment has also been associated with unemployment. ${ }^{9,10}$ Further, it has been suggested that screening for visual problems and providing free spectacles may improve the quality of life and earning potential of homeless individuals. ${ }^{5}$ Despite this, there is a paucity of literature on the eye care needs of the homeless population; little is known about how homeless patients access eye care ${ }^{4}$ or if/how their eye care needs are met.

In 2017, we created a free eye clinic in San Francisco at a homeless shelter to help bridge these gaps. The primary goal of our eye clinic is to meet the eye health needs of its residents in an effective and sustainable manner. Secondary goals of the clinic include teaching medical students basic principles about the eye examination and ophthalmologic decision making, and increasing medical student exposure to ophthalmology and community service as potential career choices.

As there are no papers to date on methods to develop a sustainable free eye clinic for homeless patients, our purpose is to outline the methodology and strategies that we employed to develop our free eye clinic. Our hope is that these strategies may serve as a template that will catalyze further efforts elsewhere.

\section{Key Steps and Strategies}

The key steps and strategies to develop a sustainable, free eye clinic for the underserved are described below.

\section{Analysis of Needs}

The first step to develop an impactful clinic is to identify the need. According to the 2018 Annual Homeless Assessment Report to Congress, half of all people experiencing homelessness were in one of the following five states: California, New York, Florida, Texas, and Washington. ${ }^{3}$ In 2018, California, Hawaii, and Oregon were found to have the highest rates of homeless individuals with 50 or more individuals per 10,000 individuals. ${ }^{3}$ Further, the highest rates of unsheltered homeless individuals in 2018 were California, followed by Oregon, Nevada, Hawaii, and Washington. ${ }^{3}$

Homeless individuals are at increased risk for various adverse health outcomes and are three to four times more likely to die compared with that of the general population. ${ }^{11}$ Specifically, eye health among the homeless population is an important consideration. Homeless patients also have poor rates of blood pressure ${ }^{12}$ and glycemic control, ${ }^{13}$ which highlights the importance of addressing these cardiovascular and ophthalmic risk factors when serving this population. ${ }^{14}$

Homeless individuals are often high utilizers of the healthcare system. ${ }^{15}$ Homelessness is associated with significantly higher emergency department use ${ }^{16,17}$ and hospital inpatient use compared with the general population that leads to substantial excess healthcare costs. ${ }^{18,19}$ Taken together, this suggests that additional safety nets and services are needed to support the healthcare needs of the homeless received

September 10, 2019

accepted after revision

January 21, 2020
DOI https://doi.org/

10.1055/s-0040-1705086. ISSN 2475-4757.
Copyright (c) 2020 by Thieme Medical

Publishers, Inc., 333 Seventh Avenue, New York, NY 10001, USA. Tel: +1(212) 760-0888.

\section{License terms}

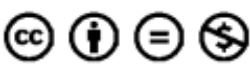


population. Given the high rates of homelessness in California, the need for ophthalmic care in the homeless population and its association with high healthcare costs, we addressed the need for a free eye clinic in San Francisco at a homeless shelter.

After performing a literature search to better understand the eye health needs of this vulnerable population, we identified a homeless shelter where we could offer our services. We leveraged infrastructure at an existing clinic that already had a physical space and the workforce in place to serve homeless individuals. Specifically, we identified a homeless shelter that already had a relationship with our institution. This homeless shelter had biweekly urgent care clinics and monthly podiatry and dermatology clinics that were run by volunteers from the University of California San Francisco (UCSF) Medical Center and School of Medicine. We approached the leadership of the homeless shelter and confirmed that the shelter would be willing to add an eye clinic to their services. We recommend a similar process of approaching the leadership of a homeless shelter even if one does not have a preexisting relationship with a clinic.

We then conducted a preliminary qualitative study including informal interviews with patients residing at this homeless shelter. The interviews consisted of a total of three interview sessions over a 2-month period where the ophthalmology resident and medical student volunteers canvassed shelter residents about their eye health. Specifically, residents were asked the following: (1) their personal medical and eye health history, (2) how they viewed the importance of their own eye health, and (3) barriers to access eye care. This allowed us to further explore and characterize the ophthalmic needs and potential obstacles to effectively provide care. Through these interviews, a total of 36 residents were interviewed. We learned that people residing at the shelter had high rates of uncorrected refractive error (67\%), diabetes (83\%), and hypertension (61\%). Seventy-five percent of those we spoke to did not know that untreated diabetes and hypertension could affect their vision. Further, $22 \%$ reported that they desired to apply for jobs; however, vision loss prohibited them from doing so.

We also identified several obstacles in meeting these needs, including difficulty obtaining affordable spectacles and navigating the complex healthcare system. Many residents did not know how to schedule an eye appointment, while others expressed distrust in the healthcare system. Some believed that providers would not effectively address their visual complaints, while others reported that seeking out eye care would be fruitless, as they believed that their eye conditions could not be treated. By interviewing residents at a homeless shelter, we highlighted the need to address ophthalmic diseases at this specific shelter and identified barriers to care to maximize our impact.

\section{Identify Champions and Stakeholders}

When identifying champions and stakeholders, it is critical to identify interested parties who are invested in serving the homeless population. Once the decision was made to open the clinic, we presented our idea to the UCSF Department of
Ophthalmology Program Director, UCSF Department of Ophthalmology Chair, and UCSF Department of Ophthalmology Director at the Zuckerberg San Francisco General Hospital to solicit their support for resident participation, department and faculty involvement, and patient referrals, respectively.

The key leaders, volunteers, and partnerships to develop a sustainable, free eye clinic at a homeless shelter are outlined in -Table 1. In addition to finding a faculty and resident champion, it is important to identify passionate volunteers who can realistically and regularly operate the clinic. Our eye clinic is run by a combination of premedical and medical student volunteers. The medical student coordinators were recruited first by a combination of sending list serve e-mails to the UCSF medical students, those in the UCSF Ophthalmology Interest Elective, and word of mouth. After confirming a 1-year commitment, the medical student coordinators were selected and they in turn recruited the medical student volunteers along with premedical students from a local college. This dedicated team allocates tasks, so that the workload is evenly distributed while also ensuring that the volunteers are serving at the level at which they have been trained (-Table 1). Based on conversations with our volunteers, it was ensured that volunteers work at their highest level of ability that maximizes their satisfaction and efficiency. At the conclusion of each clinic, the team comes together to discuss learning points and identify areas of improvement.

We found that it was important to get sponsorship for our cause on an institution level, as this gave our eye clinic credibility and allowed us to gain capable volunteers who have a sense of ownership of the clinic. We solicited support from our UCSF Department of Ophthalmology to formally endorse and affiliate the eye clinic with our academic institution. This allowed us to name our clinic the "UCSF Ophthalmology Shelter Clinic" and to include the patients that we serve in the annual department report. We also solicited support from the UCSF School of Medicine, which formalized our relationship with the medical student volunteers. By doing so, the medical student volunteers have the option of gaining credit for their volunteer work through the School of Medicine.

\section{Funding}

Funding can be one of the most difficult barriers when starting an eye clinic. Most of our funding was used to purchase essential supplies for the clinic.

When searching for funding, it is helpful to use many avenues to identify funding and to prioritize the essential equipment that is needed to get started. The majority of our funding came from The California Endowment, a nonprofit whose goals were aligned with supporting a clinic like ours. We purchased the majority of our equipment through this gift. We suggest identifying a local or state-specific nonprofit organization as a starting point; this does not necessarily need to be an ophthalmology-specific nonprofit organization. We also reached out to pharmaceutical companies and obtained the majority of our eye medications from their generous donations. By distributing our search for funding to both nonprofit organizations and private companies, we obtained the basic equipment and supplies necessary to start our clinic. We recommend 
Table 1 Key personnel to develop a sustainable eye clinic

\begin{tabular}{|c|c|c|}
\hline Key personnel & Role & Examples of tasks \\
\hline \multicolumn{3}{|l|}{ Leaders } \\
\hline $\begin{array}{l}\text { Faculty champion } \\
(n=1)\end{array}$ & $\begin{array}{l}\text { - Acts as liaison between the Depart- } \\
\text { ment of Ophthalmology and the clinic } \\
\text { - Invested in clinic sustainability }\end{array}$ & $\begin{array}{l}\text { - Forms the partnership between the shelter clinic and } \\
\text { the Department of Ophthalmology's institution } \\
\text { - Helps obtain funding for the clinic } \\
\text { - Checks in regularly with the resident champion to } \\
\text { identify problems and find solutions } \\
\text { - Recruits attending volunteers } \\
\text { - Mentors research projects }\end{array}$ \\
\hline $\begin{array}{l}\text { Resident champion } \\
(n=1)\end{array}$ & $\begin{array}{l}\text { - Oversees main clinic operations } \\
\text { - Acts as liaison between the Depart- } \\
\text { ment of Ophthalmology and the } \\
\text { medical students }\end{array}$ & $\begin{array}{l}\text { - Presents for the majority of the clinic sessions } \\
\text { - Finds solutions to optimize clinic flow } \\
\text { - Teaches medical students } \\
\text { - Recruits attending and resident volunteers } \\
\text { - Applies for funding } \\
\text { - Performs research }\end{array}$ \\
\hline $\begin{array}{l}\text { Medical student } \\
\text { coordinators ( } n=2 \text { to } \\
3 \text {; combination of } \\
\text { first and second year } \\
\text { medical students) }\end{array}$ & $\begin{array}{l}\text { - Prepare for and run each clinic session } \\
\text { - Represent the interests of the medical } \\
\text { student volunteers } \\
\text { - Represent the School of Medicine }\end{array}$ & $\begin{array}{l}\text { - Present for all clinics } \\
\text { - Communicate with service partners before and after } \\
\text { clinic to coordinate referrals } \\
\text { - Recruit medical student volunteers } \\
\text { - Enforce clinic schedule and timeliness } \\
\text { - Assist in data collection } \\
\text { - Learn about ophthalmology as a career }\end{array}$ \\
\hline $\begin{array}{l}\text { Undergraduate pre- } \\
\text { medical student coor- } \\
\text { dinators ( } n=2 \text { to } 3 \text { ) }\end{array}$ & $\begin{array}{l}\text { - Help run each clinic } \\
\text { - Support the medical student } \\
\text { coordinators }\end{array}$ & $\begin{array}{l}\text { - Equipment setup } \\
\text { - File patient charts } \\
\text { - Assist in data collection } \\
\text { - Learn about ophthalmology as a career }\end{array}$ \\
\hline \multicolumn{3}{|l|}{ Volunteers } \\
\hline $\begin{array}{l}\text { Attending volunteer } \\
(n=1)\end{array}$ & $\begin{array}{l}\text { - Oversees the clinic } \\
\text { - Ultimately is responsible for the care } \\
\text { delivered } \\
\text { - Teaches learners of all levels }\end{array}$ & $\begin{array}{l}\text { - Confirms the diagnosis and management of each } \\
\text { patient } \\
\text { - Signs off on each patient encounter } \\
\text { - Performs a wrap up teaching session }\end{array}$ \\
\hline $\begin{array}{l}\text { Resident or fellow } \\
\text { volunteer }(n=1)\end{array}$ & $\begin{array}{l}\text { - Assists and teaches the medical stu- } \\
\text { dent volunteers } \\
\text { - Mentors the medical students }\end{array}$ & $\begin{array}{l}\text { - Coaches the medical student volunteers on the } \\
\text { diagnosis and decision-making prior to their pre- } \\
\text { sentation to the attending } \\
\text { - Medical student mentorship }\end{array}$ \\
\hline $\begin{array}{l}\text { Medical student vol- } \\
\text { unteers ( } n=4 \text { or } 5)\end{array}$ & $\begin{array}{l}\text { - See patients } \\
\text { - Practice presentations } \\
\text { - Develop ophthalmologic, decision- } \\
\text { making and health coaching skills }\end{array}$ & $\begin{array}{l}\text { - Collect history and perform eye exam } \\
\text { - Present to the attending with the help of the resi- } \\
\text { dent or fellow } \\
\text { - Perform health coaching } \\
\text { - Learn about ophthalmology as a career }\end{array}$ \\
\hline $\begin{array}{l}\text { Optometrist volun- } \\
\text { teers }(n=1 \text { or } 2)\end{array}$ & $\begin{array}{l}\text { - See patients } \\
\text { - Assist and teach learners of all levels }\end{array}$ & $\begin{array}{l}\text { - See a larger number of patients than the medical } \\
\text { students } \\
\text { - Assist with refraction }\end{array}$ \\
\hline \multicolumn{3}{|l|}{ Partnerships } \\
\hline $\begin{array}{l}\text { University of } \\
\text { California San } \\
\text { Francisco (UCSF) } \\
\text { Department of } \\
\text { Ophthalmology }\end{array}$ & $\begin{array}{l}\text { - Endorse the clinic } \\
\text { - Ensure the sustainability of the clinic }\end{array}$ & $\begin{array}{l}\text { - Support the faculty and resident champion } \\
\text { - Help identify funding } \\
\text { - Facilitate patient follow-up }\end{array}$ \\
\hline $\begin{array}{l}\text { UCSF School of } \\
\text { Medicine }\end{array}$ & $\begin{array}{l}\text { - Support the medical student volun- } \\
\text { teer experience }\end{array}$ & $\begin{array}{l}\text { - Integrate the clinic experience into the formal ex- } \\
\text { tracurricular activities of the students }\end{array}$ \\
\hline $\begin{array}{l}\text { Project Homeless } \\
\text { Connect (PHC) }\end{array}$ & $\begin{array}{l}\text { - Nonprofit organization that accepts } \\
\text { our referrals for free spectacle correc- } \\
\text { tion at their monthly "Optical Day" }\end{array}$ & $\begin{array}{l}\text { - The medical student coordinators email PHC after } \\
\text { each clinic with the eyeglass prescriptions and list of } \\
\text { patients who will present to "Optical Day" for their } \\
\text { free eyeglasses }\end{array}$ \\
\hline $\begin{array}{l}\text { Zuckerberg San Fran- } \\
\text { cisco General } \\
\text { Hospital }\end{array}$ & $\begin{array}{l}\text { - Local county hospital that accepts our } \\
\text { referrals for advanced ophthalmologic } \\
\text { care and longitudinal follow-up }\end{array}$ & $\begin{array}{l}\text { - The medical student coordinators provide patients } \\
\text { with a prespecified date and time at the county } \\
\text { hospital that is within } 4 \text { days of being evaluated at } \\
\text { our clinic }\end{array}$ \\
\hline
\end{tabular}


identifying more than one source of funding ideally from a variety of industries (i.e., nonprofit organizations, private companies, and academic institutions).

\section{Logistics}

The above steps took approximately 4 months to complete. At this point, we had a physical space for our clinic with potential patients, passionate volunteers, and the basic equipment and supplies necessary to get started. The last step was to determine operational logistics of the clinic. One of our goals was to make follow-up for our patients as seamless as possible. Given that our partner nonprofit's "Optical Day" was the second Monday of each month, we decided to hold our eye clinic on either the first Monday or Wednesday of each month so that referral to "Optical Day" was within a close follow-up time. As mentioned above, the accepting county hospital agreed to see our patients within 4 days of referral. Accordingly, we identified preapproved appointment times to give to our referred patients, so that they knew the time and location of their follow-up appointment at the time of referral.

Our first clinic was a pilot clinic to further characterize the logistics of our clinic, work out any potential obstacles with the physical space and equipment, and orient the volunteer leadership team. This pilot clinic was attended only by the volunteer leadership team (i.e., premedical and medical student coordinators, resident champion, and faculty champion) with the goal of seeing a small number of patients. This pilot clinic was organized by the resident and faculty champion and the vision was then explained to the volunteer leadership team. Each clinic then expanded from there as an iteration from the previous clinic, with particular attention to optimizing the logistics.

\section{Limitations and Obstacles}

While performing complete ophthalmologic examinations in the eye clinic are sufficient for many patients, it is also important to understand the limitations of the clinic to fully meet patient needs and provide appropriate care. We identified several such limitations in our clinic. The first significant limitation involved finding a way to obtain spectacles for our patients who did not have the ability to purchase them. We identified a local nonprofit organization called Project Homeless Connect that had the resources to provide free spectacles. Given our similar goals and mission, we formed a partnership with this organization that agreed to accept our referrals to their monthly "Optical Day." We provide patients with spectacle prescriptions and the patients then present to "Optical Day" to obtain free spectacles (-Table $\mathbf{1}$ ).

Another limitation of our eye clinic was an inability to provide more advanced ophthalmologic care if necessary (i.e., intravitreal injections, laser, and surgery). A partnership was formed with the Chief of Ophthalmology at the local county hospital (Zuckerberg San Francisco General Hospital) to accept referrals from the eye clinic if advanced ophthalmologic care was indicated (-Table $\mathbf{1}$ ). In fact, the county hospital evaluates our referred patients within 4 days of our eye clinic, which maximizes the potential for follow-up in this vulnerable population. When referring patients to the country hospital, the medical students perform health coaching centered on the patients' values and the reason for referral to hopefully address patients' potential concerns and/or existing distrust in the healthcare system.

Lastly, the high turnover rate in the leadership of the clinic, which is run primarily by medical students in their preclinical years, is a limitation in our clinic. We addressed this challenge by confirming a year-long commitment with the volunteer leaders of the clinic and training the new volunteer leaders 3 to 4 months in advance.

\section{Important Points}

\section{Sustainability is Critical}

Our eye clinic has been in operation for over 2 years, which is a testament to our emphasis on sustainability. We focused on sustainability during each step of development and started small to ensure each patient received comprehensive care. Our goal remains to continue growing sustainably.

\section{Measure Outcomes and Impact Prospectively}

We have served a total of 131 patients to date in our clinic. Of these 131 patients, we have referred 78 patients for spectacle correction and 33 patients to the local county hospital for more advanced ophthalmologic care. Of those patients referred to the county hospital, 16 patients had glaucoma or were glaucoma suspects, 9 patients had visually significant cataracts, and 16 patients had diabetic retinopathy (12 patients with nonproliferative diabetic retinopathy and 4 patients with proliferative diabetic retinopathy). Of the patients who were referred for free spectacle correction and to the county hospital, 35 and $42 \%$ presented to their appointments, respectively. We are actively measuring outcomes to guide our decisions about the clinic prospectively to quantify our impact and improve follow-up rates. We also use this data when advocating for additional funding and support.

\section{Education}

Education is at the center of an academic institution. To date, over 65 medical students, approximately 10 premedical students, and 10 optometrists have volunteered at our clinic. The clinic provides an additional forum to train future physicians and eye professionals.

\section{Recruitment}

An institution's support of a free eye clinic for underserved populations enhances its reputation and provides a foundation upon which to recruit like-minded faculty. It also serves as an appealing differentiator for resident recruitment. Thus far, over $35 \%$ of our ophthalmology faculty and $70 \%$ of our ophthalmology residents have volunteered at the clinic.

\section{Summary}

This paper outlines the methodology and strategies that we used to develop an effective and sustainable free eye clinic for a homeless population in San Francisco. To be successful, it is 
important to perform an analysis on needs, enlist passionate champions and stakeholders, understand the limitations and potential obstacles, obtain funding and iterate upon the logistics of the clinic. Our hope is that these strategies may serve as a template that will catalyze further efforts elsewhere in the care of a very vulnerable population.

\section{Note}

Supported in part by NIH-NEI EY002162-Core Grant for Vision Research and by an unrestricted grant from Research to Prevent Blindness, the United States.

\section{Conflict of Interest \\ None declared.}

\section{Acknowledgments}

We would like to acknowledge The California Endowment for their generous gift to purchase essential equipment for our clinic along with Akorn Pharmaceuticals for their generous donation of eye medications for use at our clinic. We would also like to acknowledge all those who have volunteered at our eye clinic.

\section{References}

1 Tsai J, O'Toole T, Kearney LK. Homelessness as a public mental health and social problem: New knowledge and solutions. Psychol Serv 2017;14(02):113-117

2 Tsai J. Lifetime and 1-year prevalence of homelessness in the US population: results from the National Epidemiologic Survey on Alcohol and Related Conditions-III. J Public Health (Oxf) 2018;40 (01):65-74

3 Henry M, Mahathey A, Morrill T, Robinson A, Shivji AWatt R; Abt Associates. The 2018 Annual Homeless Assessment Report (AHAR) to Congress. 2018 Part I. Available at: https://www. hudexchange.info/onecpd/assets/File/2013-AHAR-Part-2.pdf. Accessed February 4, 2020

4 D'Ath PJ, Keywood LJ, Styles EC, Wilson CM. East London's Homeless: a retrospective review of an eye clinic for homeless people. BMC Health Serv Res 2016;16:54

5 Nia J, Wong D, Motamedinia D. The visual acuity and social issues of the homeless population in Toronto. Univ Tor Med J 2003;80 (02):84-86
6 Maberley DA, Hollands H, Chang A, Adilman S, Chakraborti B, Kliever $\mathrm{G}$. The prevalence of low vision and blindness in a Canadian inner city. Eye (Lond) 2007;21(04):528-533

7 Institute of Medicine (US) Committee on Health Care for Homeless People. Health problems of homeless people. In: Homelessness, Health, and Human Needs. National Academies Press (U.S.); 1988. Available at: https://www.ncbi.nlm.nih.gov/books/NBK218236/. Accessed March 31, 2019

8 Ho JH, Chang RJ, Wheeler NC, Lee DA. Ophthalmic disorders among the homeless and nonhomeless in Los Angeles. J Am Optom Assoc 1997;68(09):567-573

9 Cumberland PM, Rahi JS; UK Biobank Eye and Vision Consortium. Visual function, social position, and health and life chances: The UK Biobank study. JAMA Ophthalmol 2016;134(09):959-966

10 Braithwaite T, Verlander NQ, Peto T, et al. National Eye Survey of Trinidad and Tobago (NESTT): prevalence, causes and risk factors for presenting vision impairment in adults over 40 years. $\mathrm{Br} \mathrm{J}$ Ophthalmol 2020;104(01):74-80

11 O'Connell JJ. Premature mortality in homeless populations: a review of the literature. Available at: https://pdfs.semanticscholar.org/7ffe/ 06c2a73bede5bbc4b3aaf5b3782f61b779aa.pdf?_ga=2.158191802. 1610078745.1580809334-1889254951.1561091521. Accessed February 4, 2020

12 Asgary R, Sckell B, Alcabes A, Naderi R, Schoenthaler A, Ogedegbe G. Rates and predictors of uncontrolled hypertension among hypertensive homeless adults using New York City shelter-based clinics. Ann Fam Med 2016;14(01):41-46

13 Hwang SW, Bugeja AL. Barriers to appropriate diabetes management among homeless people in Toronto. CMAJ 2000;163(02): 161-165

14 Baggett TP, Liauw SS, Hwang SW. Cardiovascular disease and homelessness. J Am Coll Cardiol 2018;71(22):2585-2597

15 Padgett D, Struening EL, Andrews H. Factors affecting the use of medical, mental health, alcohol, and drug treatment services by homeless adults. Med Care 1990;28(09):805-821

16 LaCalle EJ, Rabin EJ, Genes NG. High-frequency users of emergency department care. J Emerg Med 2013;44(06):1167-1173

17 Padgett DK, Struening EL, Andrews H, Pittman J. Predictors of emergency room use by homeless adults in New York City: the influence of predisposing, enabling and need factors. Soc Sci Med 1995;41(04):547-556

18 Hwang SW, Weaver J, Aubry T, Hoch JS. Hospital costs and length of stay among homeless patients admitted to medical, surgical, and psychiatric services. Med Care 2011;49(04):350-354

19 Salit SA, Kuhn EM, Hartz AJ, Vu JM, Mosso AL. Hospitalization costs associated with homelessness in New York city. N Engl J Med 1998;338(24):1734-1740 